\title{
FDA Established Names and Unique Ingredient Identifier Codes Terminology
}

National Cancer Institute

\section{Source}

National Cancer Institute. FDA Established Names and Unique Ingredient Identifier Codes

Terminology. NCI Thesaurus. Code C63923.

The terminology that includes terms pertaining to FDA/USP Substance Registration System (SRS), which is to support health information technology initiatives by generating unique ing redient identifiers (UNIIs) for substances in drugs, biologics, foods, and devices. 